\title{
Facies and Sequence Stratigraphic Study of Bema Field, Niger Delta, Nigeria
}

\author{
${ }^{* 1}$ JAMABO, BF; ${ }^{2}$ OKENGWU, KO
}

Department of Geology, University of Port Harcourt, PMB 5323, Port Harcourt, Nigeria

"Corresponding Author; Email: kingsley.okengwu@uniport.edu.ng;Tel: +2348036671300

\begin{abstract}
Facies architecture and sequence stratigraphic framework of a potential hydrocarbon Prospective Area of Bema Field, Central Swamp Depobelt, Niger Delta was investigated. This study utilized Well Logs, Side Well Samples, Biostratigraphic Data and 3-D Seismic. The study revealed four facies unites, namely, Sandstone facies (SF), Shaly-Sandsone facies (SSF), Mudsone facies (MF), and Heterolithic facies (HF). The Sequence Stratigraphic analysis of the field revealed Nine (9) stratigraphic surfaces, comprising of (Five Maximum Flooding Surfaces (MFSs) with ages ranging from 20.7 to $15.0 \mathrm{Ma}$, and Four Sequence Boundaries (SBs) with ages between 20.4 and 15.5 Ma respectively). Five Vail's third order depositional sequences (SQ1, SQ2, SQ3, SQ4, and SQ5) and four (4) Galloway's genetic sequences (GQ1, GQ2, GQ3 and GQ4) were recognized within the study area based on Stratigraphic Marker tops and system tracts. Hydrocarbon play assessment revealed that the HST and TST are key reservoir rocks in the study while the shale of the TST therefore forms the seal for the potential traps in the study area.
\end{abstract}

\section{DOI: https://dx.doi.org/10.4314/jasem.v25i12.1}

Copyright: Copyright $\odot 2021$ Jamabo and Okengwu. This is an open access article distributed under the Creative Commons Attribution License (CCL), which permits unrestricted use, distribution, and reproduction in any medium, provided the original work is properly cited.

Dates: Received: 22 August 2021; Revised: 17 September 2021; Accepted: 06 October 2021

Keywords: Facies, Bounding Surfaces Maximum Flooding Surfaces, Stratigraphic Marker, Sequences.

Facies analysis is an important tool for understanding heterogeneities associated with reservoirs and a tool use for interpretation of accurate exploration and production of hydrocarbons from these reservoir rock. The Interpretations from lithofacies observation are clearly utilized to describe and unravel all heterogeneities associated with the understudied reservoir and will definitely give rise to a better and accurate exploration and production of hydrocarbons from these reservoir. Relevant facies information gotten for properly interpretion includes; lithology, structures, fossil content, ichnofossils, size of grains, degree of sorting, roundness, porosity, pore arrangement, and the ease at which fluids flows through these pores. These facies properties are the major determinants of excellent reservoir quality and are the building blocks in understanding the depositional environments of reservoirs. Sequence stratigraphy helps in inferring the dispersal of muds, shale and other fine-grained sediments which act as closures and baffles for fluid flow within reservoir sequences and as hydrocarbon source rocks (Posamentier and Allen, 1999). A clear understanding and application of sequence stratigraphy plays a key drive for accurate interpretation of geometry of facies, structural trend, stratigraphic configuration and hydrocarbon distribution within a field. This research clearly focuses on integrating lithofacies study and seismic stratigraphy in other to accurately build a realistic sequence stratigraphic framework so as to enable prediction and placements of reservoirs, source and seal rocks within the study area. In the Niger-Delta petroleum province, many dry holes and poorly producing wells are attributed to poor architectural knowledge of reservoirs. Sequence stratigraphy does not only reduce uncertainty of finding prospects, it also helps for planning adequate production schemes by identifying inter-well drill location. Therefore, the present study apply facies architecture and sequence stratigraphic framework of Bema Field, Central Swamp Depobelt, Niger Delta, Nigeria.

\section{MATERIALS AND METHODS}

Area of Study: The study area "Bema Field" lies within the Central Swamp depobelt of the Niger-Delta (Fig. 1). This is within the geographic boundaries of latitudes $5^{\circ} 00^{\prime} \mathrm{N}$ to $8^{\circ} 00^{\prime} \mathrm{N}$ and longitudes $4^{\circ} 00^{\prime} \mathrm{E}$ to $6^{\circ} 00^{\prime} \mathrm{E}$ of the Greenwich meridian. A total of seven wells, located within the Bema Field are shown on figure 2 .

Regional Stratigraphic Framework: The lithic fill of the Niger Delta Basin ranges from facies of the first major Cenozoic transgression to the depositional products of the present day, as well as materials eroded from subsurface and outcropping formations (Adegoke et al., 2017). The stratigraphy include: 
Benin Formation: This sedimentary unit overlies the Agbada formation and appears to be the youngest stratigraphic unit in the Niger-Delta (Fig. 3). This unit is composed of continental fluvial sands estimated to be approximately 3050m thick (Adegoke et al., 2017). The unit is friable and comprises of white, fine to coarse and pebbly, poorly sorted sands. Occasionally, thin streaks of lignite occur as finely dispersed fragments. According to Short and Stauble, 1967, the Benin Formation is aged from the Eocene to Recent.

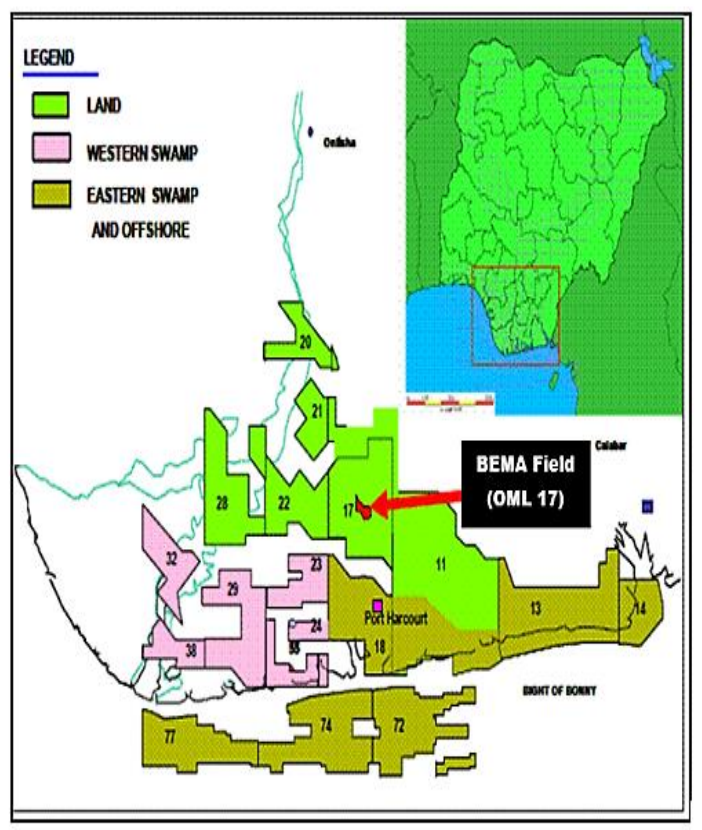

Fig 1: Map showing the location of BEMA Field in the Central Swamp Depobelt, Niger Delta.

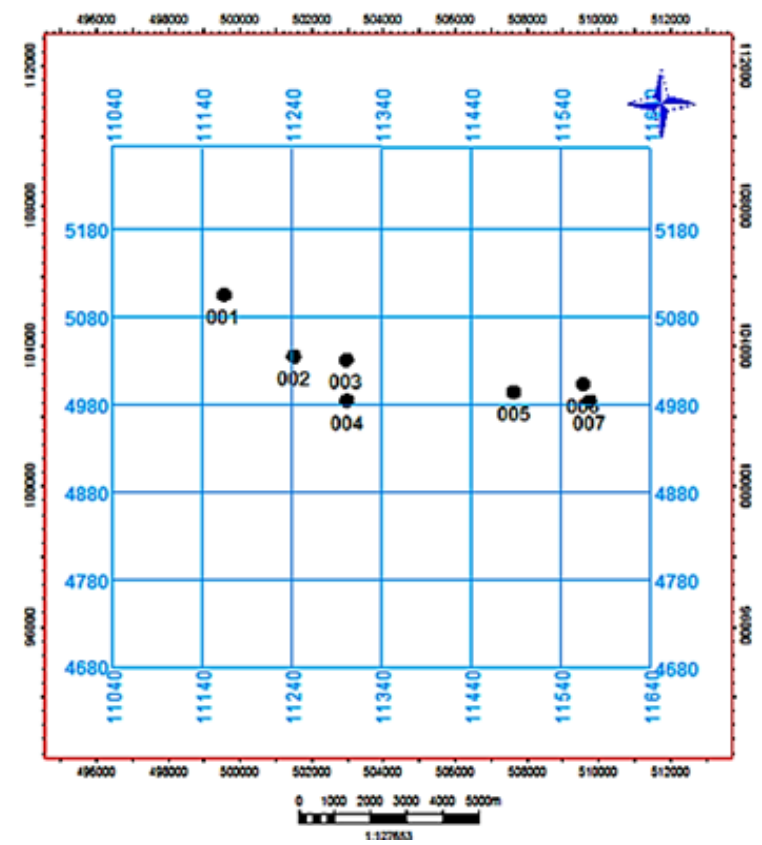

Fig 2. Map showing the wells distribution within Bema Field
Agbada Formation: The Agbada formation underlies the Benin formation and overlies the Akata formation (Fig. 3). The stratigraphic unit is mainly a mixture of sands and shales in paralic sedimentation. According to Adegoke et al., 2017, the Agbada formation is said to be diachronous with an age range from Eocene to recent time. According to Reijers, 1995, facies identified in the Agbada formation can be grouped into seven lithofacies association as follows; i) Coastal barrier or shoreface; ii) Back barrier (lagoonal delta or crevasse splay); iii) Distributary channel; iv) Lagoonal system; v) Transgressive sand; vi) Suspension fall-out; vii) Allochthonous lumps. According to Adegoke et al., 2017, the Agbada Formation is observed to form the hydrocarbon prospective sequence in the NigerDelta and these consistencies are clearly observed in all depobelts.

Akata Formation: According to Short and Stauble, 1967, it is vehemently believed that the Akata Formation is the oldest stratigraphy in the Niger-Delta. Adegoke et al., 2017, observed the formation to basically contain marine shales that are predominant at the pro-deltaic part of the Delta and it is believed to be the major source rock for all petroleum deposits with in the Niger-Delta (Fig. 3). The Formation is the major time transgressive lithological unit of the Delta. The thickness of the Agbada formation ranges from 2,000ft to 20,000 ft (Adegoke et al., 2017). Based on planktonic foraminifera abundance, the deposits of Akata is inferred to have been deposited in a deep open marine shelf setting, having a age range from Paleocene to Holocene (Short and Stauble, 1967).

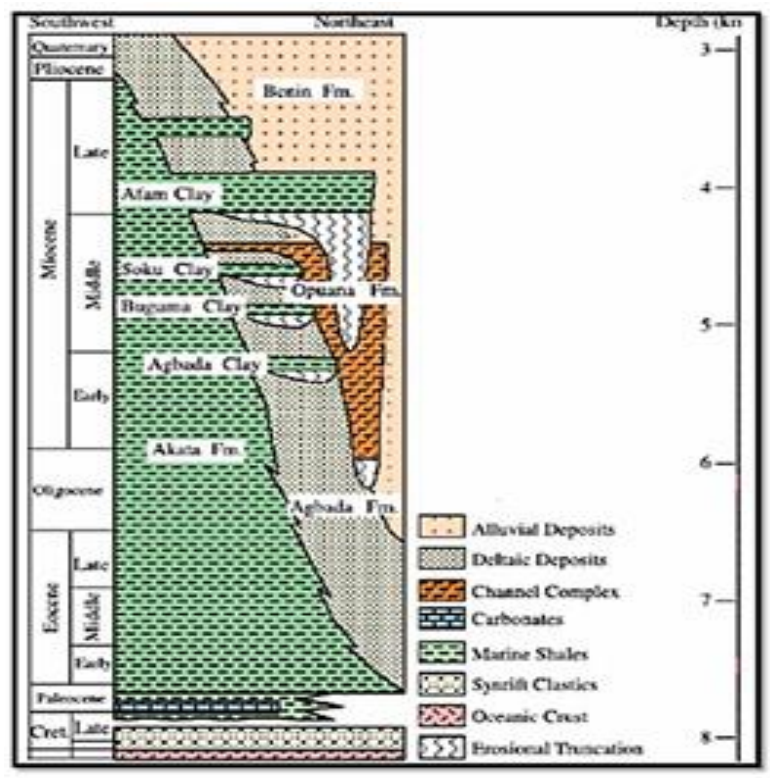

Fig 3: Stratigraphic column of the Tertiary Niger Delta (Modified from Doust and Omatsola, 1990) 


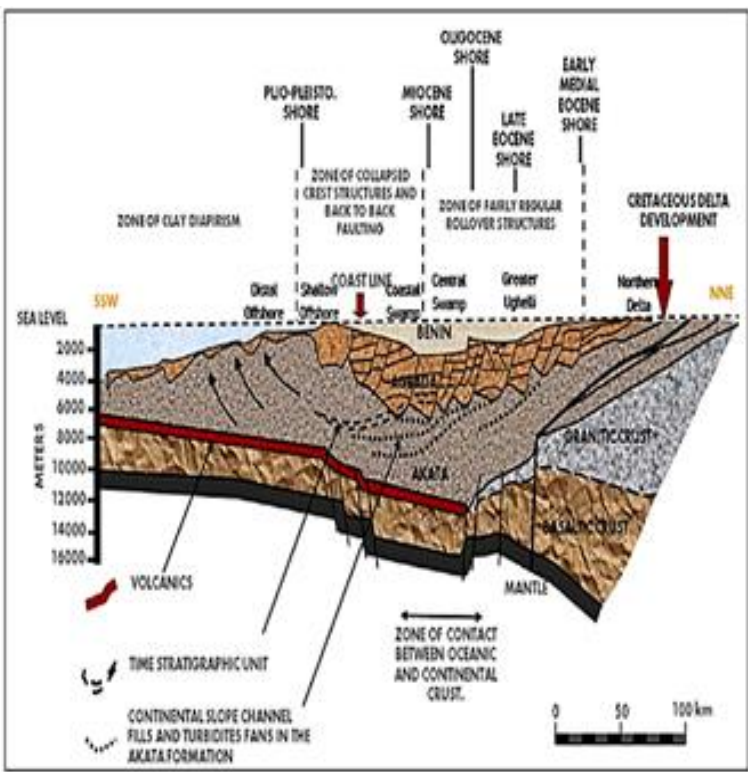

Fig 4: Dip section of the Niger Delta Basin showing structure, stratigraphy and depobelts (Modified after Doust and Omatsola, 1990)

Depositional Belt: The subdivision of the whole Delta into depositional belts, also called depobelts is anchored on the recognition of regional basin faults. The delta is hence divided into six depobelts (Knox and Omatsola, 1987) which represent numerous stages of deltaic growth and development (Fig. 4). The depobelts gets progressively younger from the onshore to the offshore and deep offshore realms (basinward) and ranges in Eocene age in the northern part to Pliocene age, offshore of the recent shoreline. The proximal depobelts shows an extensional stress system while the distal depobelts shows transitional to compressional tectonics. The well-defined deposition of the three deltaic formations in the Niger-Delta happened in each of five offlapping sedimentation cycles. These cycles also called depobelts are approx. 30 to $60 \mathrm{~km}$ in width and progrades over basaltic crust into Guinea's Gulf. The various depobelts are delineated by syn-sedimentary growth faults occurring in response to the interplay of rates of sediment supply and deltaic subsidence (Doust and Omatsola 1990). Each of the six depobelts contain distinct depositional cycle (shallowing-upward) with its individual marine, paralic, and continental sediments and they describe a succession of breaks in the Delta's progradation. The depobelts as documented by Steele (2009) in the Niger-Delta from the oldest to the youngest are as follows; Northern Depobelt, Greater Ughelli Depobelt, Central Swamp Depobelt, Coastal Swamp Depobelt, Shallow Offshore Depobelt, and the Distal Offshore Depobelt. The research area resides within the Central Swamp Depobelt.

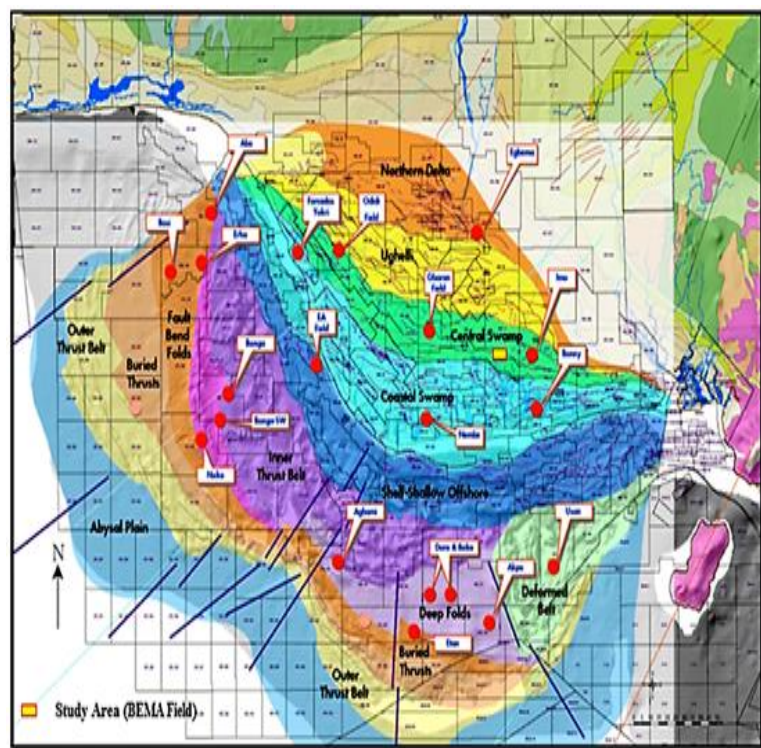

Fig 4: Map showing the various depobelts, structural play elements and study area in the Niger Delta Basin (Steele, 2009)

Niger-Delta Sequence Stratigraphic Framework: In the Niger-Delta, sequence stratigraphy is best approached by depobelt. This is clearly justified on the grounds that the fundamentals of the Deltaic succession are cyclic oflapping parasequence sets. All individual parasequence clearly consists of marine shales represented by dateable extreme flooding surfaces which are succeeded upward by proximal fluvio-marine silts, sands, clays overlain by both shoreface sands and coastal plains sands.

\section{RESULTS AND DISCUSSION}

Sedimentary Lithofacies: Lithofacies identification from the Well Log classified the stratigraphic sequences in the study area into four predominant lithofacies which includes; sandstone facies, mudrock facies, shaly-sandstone facies and heterolithic facies (Fig. 5). These facies are a result of deposition of modification that occurred in a particular depositional setting.

Sandstone Facies: The Sandstones Facies as revealed from side wall samples are fine to coarse-grained, brownish in colour, moderately to well sorted, loosely consolidated with no observable sedimentary structure. Muscovite, micas and pyrite are common assessor minerals associated with the sandstone facies of Bema field. The presence of pyrite suggests oxidation activities, indicating that the sands were definitely deposited in an oxic environment. On the gamma ray log, the sandstone Facies are massive and have blocky to bell shaped motifs. These motifs are clearly indicative of channel fill deposits and shoreface sands. 


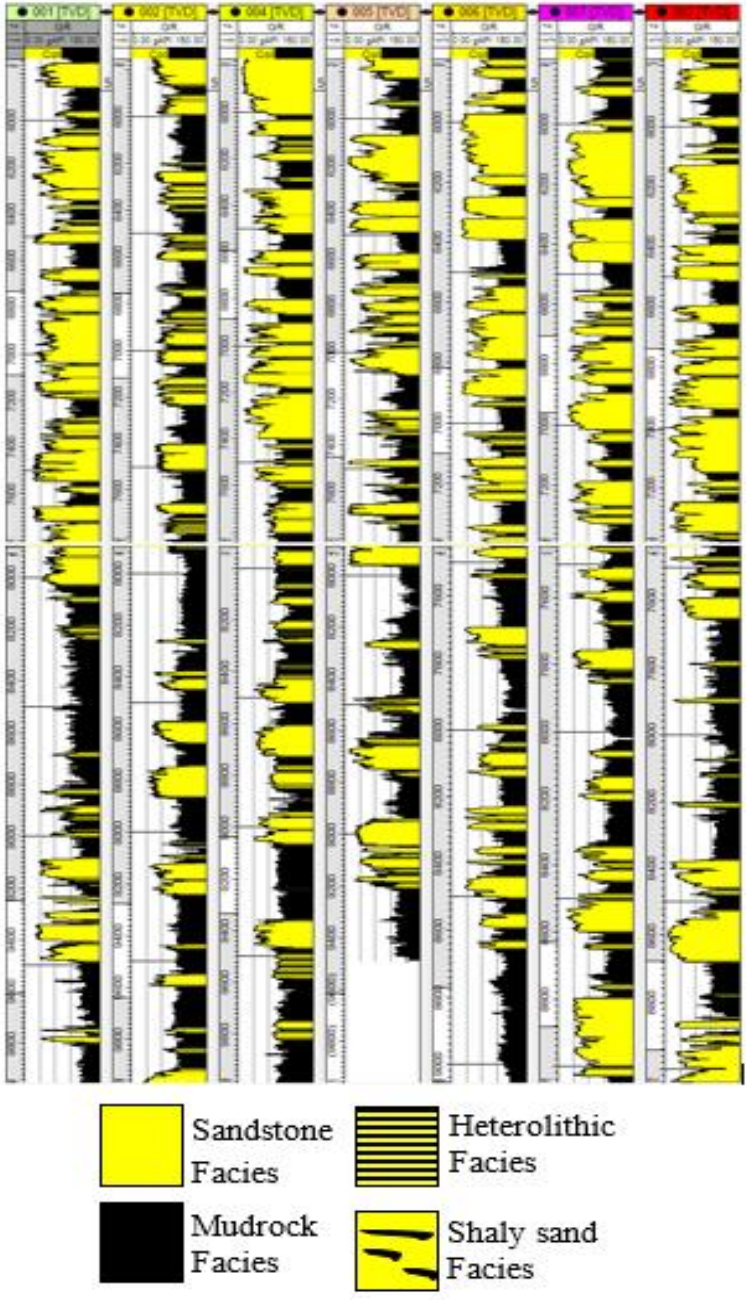

Fig 5: Well Log Lithofacies Identified Across Bema Field

Shaly Sandstone Facies: The Shaly Sandstone Facies are gray to brownish in appearance, fine to mediumgrained, silty, moderately sorted, loosely consolidated with no observable sedimentary structure. The intercalated shales are calcareous in some sand bodies. On GR log, the shaly sandstone facies are basically that of the blocky and funnel shaped motifs with several serrations. The serrations are a consequence of fluctuation in current strength which may result from tidal activities. Such tidal activities are most dominant in estuarine and deltaic environmental settings.

Heterolithic Facies: Heterolithics Facies are found as thin sand shale beds juxtaposition. Heterolithic Facies forms in response to alternations in tidal velocity and sediment supply. The fluctuations result in the interbedded layers of mudrock and sandstone. The mud is sedimented during slack tide periods while the sandstone layer is formed during high tidal currents. These are mainly related with estuaries and deltaic environments. On the GR log, the heterolithic facies are found in many cases below thick channel sands on the GR $\log$ motif.

Mudrock Facies: These facies are dark grey, very calcareous in some wells, silty, frangible, well sorted with no observable sedimentary structure. In some of the sampled depths, side wall samples revealed that they are fissile. On well logs, the mudrock facies exhibit a retrogradational stacking arrangement which is fairly continuous. The mudrock facies contains high abundance and diversity of marine fossils indicative of marine environmental settings.

\section{Well log Sequence Stratigraphic Interpretation}

Maximum Flooding Surface (MFS): The MFSs identified on well logs were carefully attributed by dense extensive shaly intervals that separated overall thinning-upward intervals from thickening-upward intervals. The biostratigraphic markers utilized for zonation is presented in Table 1. Five MFSs were clearly observed and correlated across the field (Fig. 5). From oldest to youngest, the observed maximum flooding surfaces are described. The oldest MFS identified is the 20.7 Ma (20.7 Ma MFS). This MFS was dated using the Alabamina 2 regional marker. This MFS occurs within P650 biozone. The MFS was only identified in well 004 at $13900 \mathrm{ft}$ which is the deepest well in the Bema Field. The $19.4 \mathrm{Ma}$ Maximum Flooding Surface was clearly observed in well 4 and correlated across to well 001 and 002 . The marker bed utilized for the clear observation of this surface is the Ogara Shale. This MFS happens to show visibility within F9300 and P670 biozones. The 17.4 Ma maximum flooding surface was clearly observed as regards to high abundance and diversity of foraminifera. The surface is clearly observed amongst F9300 and P680 biozones and was accurately correlated across all seven wells in Bema Field. The 15.9 Ma MFS was identified, dated and correlated across the field using the index marker Chiloguembelina 3. The youngest MFS observed in the Field is the 15.0 Ma Maximum Flooding Surface (15.0 Ma MFS). This surface lies within the F9500 and P680 biozones. The surface was dated using the Bolivina-25 index marker. 


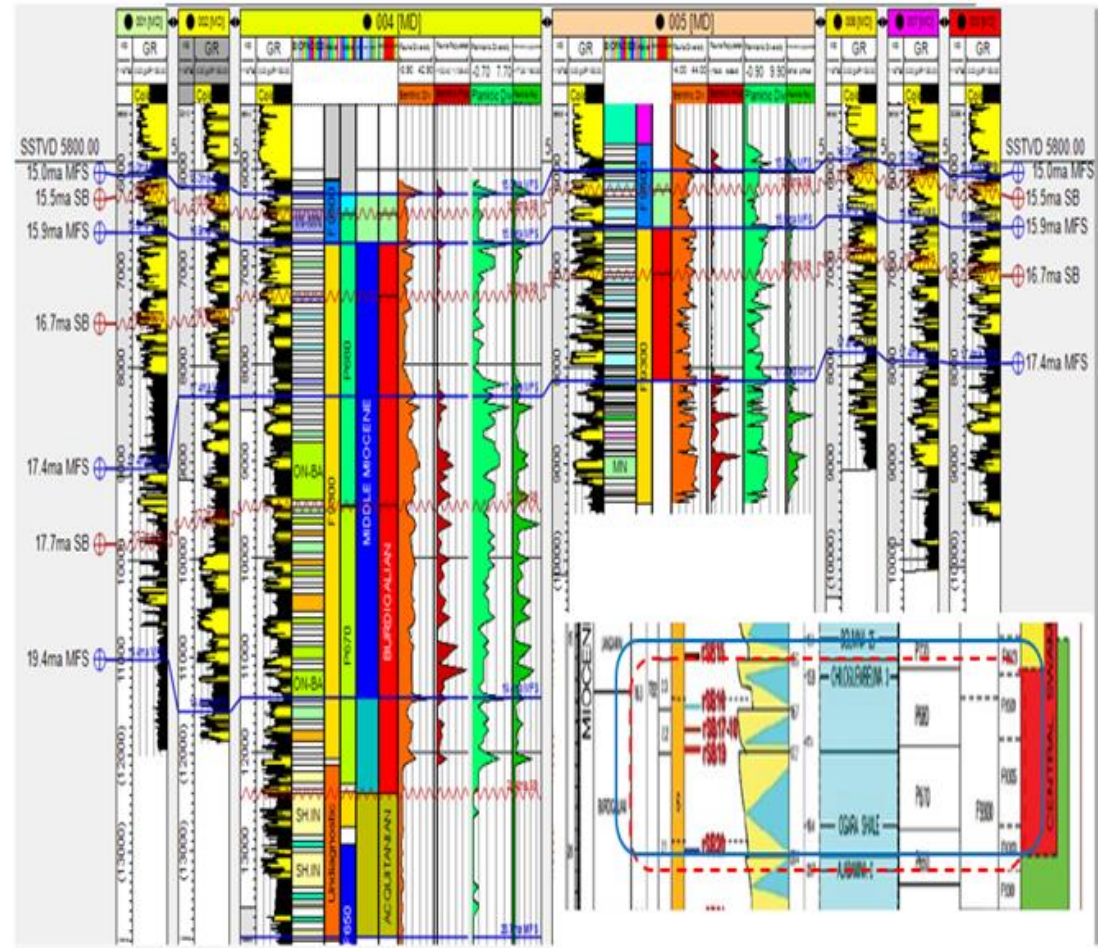

Fig 5: Major sequence Stratigraphic surfaces identified in Bema Field using well logs, biostratigraphy and Niger-Delta Chronostratigraphic Chart

The depth at which the Maximum Flooding Surfaces occurred in wells with fossil records is summarized in Table 1.

Table 1: Summary Sheet for delineated MFS, Marker Fauna and Biozone in the Study Wells

\begin{tabular}{llllll}
\hline \multirow{2}{*}{ Wells } & \multirow{2}{*}{ Depth (ft) } & \multirow{2}{*}{ MFS age (Ma) } & \multirow{2}{*}{ Marker Fauna } & \multicolumn{2}{l}{ Biozone } \\
\cline { 5 - 6 } & & & P Zone & F Zone \\
\hline 005 & 5974 & 15.0 & Bolivina-25 & P680 & F9500 \\
005 & 6564 & 15.9 & Chiloguembelina 3 & P680 & n.a. \\
005 & 8138 & 17.4 & n.a. & P680 & F9300 \\
004 & 6250 & 15.0 & Bolivina-25 & P680 & F9500 \\
004 & 6750 & 15.9 & Chiloguembelina 3 & P680 & n.a. \\
004 & 8330 & 17.4 & n.a. & P680 & F9300 \\
004 & 11434 & 19.4 & Ogara Shale & P670 & F9300 \\
004 & 13900 & 20.7 & Alabamina 2 & P650 & n.a. \\
\hline
\end{tabular}

Sequence Boundary (SB): Four sequence boundaries were recognized from well logs in the Bema Field (Fig. 5 b), these include; $20.4 \mathrm{Ma}$ sequence boundary recognized only in well 004 ,

17.7 Ma sequence boundary recognized in well 001, 002 and 004, 16.7 Ma sequence boundary recognized in all wells in the field, and 15.5 Ma sequence boundary recognized in all wells in the field.

The SBs were observed on sand bodies having rapid and sharp bases of dense sand units separating thickening-upward intervals from finingupward intervals.

System-tracts and Depositional Sequences: Three system-tracts were identified in the course of the research and were correlated across the Field. These were the visible Lowstand System-Tract (LST), visible Transgressive System-Tract (TST) and visible Highstand System-Tract (HST) (Fig. 6). The identified system tracts aided in the recognition of reservoirs sands (sand bodies in Lowstand System Tracts and Highstand
System Tracts), seals and source rocks (Transgressive System tracts and Highstand System Tracts).

The system-tracts are of variable thicknesses that appear to be structurally controlled as revealed from the correlation cross section in Petrel Software window. The average percentage thickness coverage of system-tracts varies across wells such that LST accounts for $40 \%$ of the system tracts, $10 \%$ for TST and $50 \%$ for the HST. 


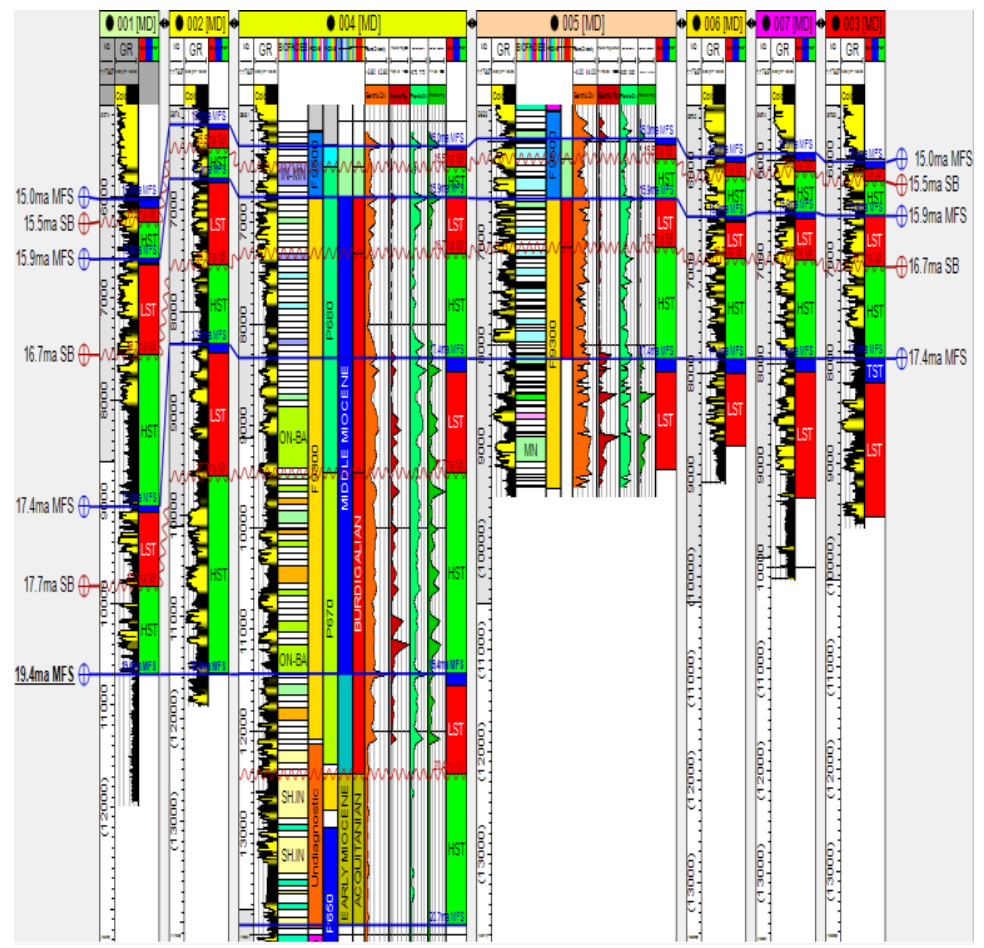

Fig 7: Well logs showing the system tracts identified and correlated across the Bema

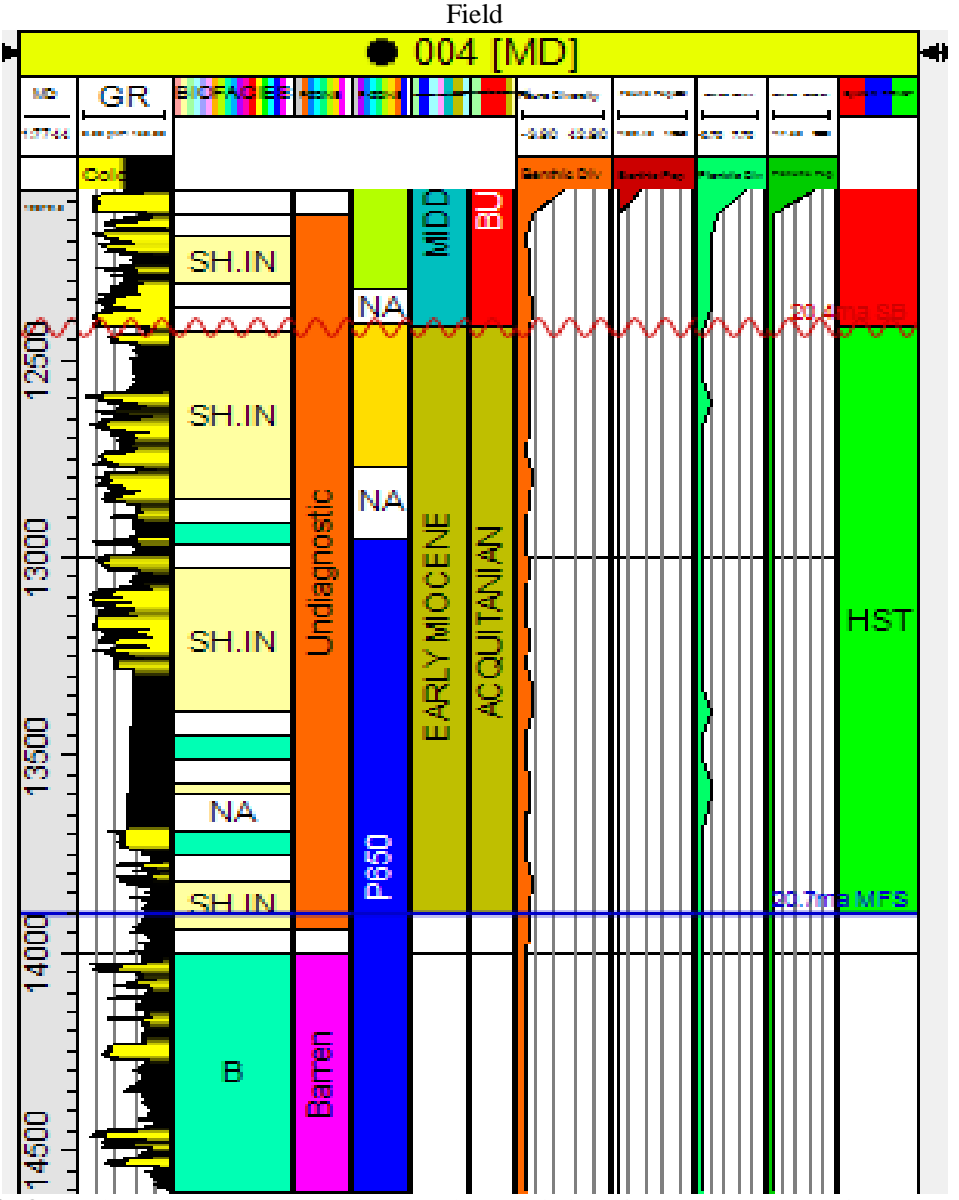

Fig 8: Well section window showing the characteristics of Sequence 1 (SQ1) in well 004
Posamentier and Vail, (1988) defined a depositional sequence as the interval of rocks between two consecutive sequence boundaries, while Galloway (1989) defined a genetic sequence as the rock interval between two consecutive Marine Flooding Surfaces (MFS). Five (5) Vail's depositional sequences (SQ1, SQ2, SQ3, SQ4, SQ5) and four (4) Galloway's inherent sequences (GQ1, GQ2, GQ3 and GQ4) were clearly identified within the study area based on stratigraphic marker surfaces and system tracts.

Details of these identified stratigraphic sequences are discussed below:

Sequence 1 (SQ1): This sequence is approximately $1482 \mathrm{ft}$ thick and is confined at the lower level by the 20.7 Ma MFS indicator (Alabamina 2) and at the upper level by the 20.4 Ma sequence boundary. This is actually the oldest depositional sequence in the study Field and is found only at the greatest depth in the well (Well 004) which is of Early Miocene in Age and is well deposited within the shallow inner neritic paleo-depositional environment. This observable depositional sequence is incomplete, reflecting only Highstand System Tracts that clearly consists of progradational to aggradational parasequences (fig. 7 and 8), suggesting upper and lower shoreface sands, capped by channel sand deposits and flood plains sediments.

Sequence 2 (SQ2): This sequence is approximately $883 \mathrm{ft}$ thick in well $001,1920 \mathrm{ft}$ in well 002 and $2927 \mathrm{ft}$ in well 004. In well 001 and 002, the depositional sequence is incomplete, reflecting basically only highstand system tract. In well 004, the depositional sequence is complete, reflecting Lowstand, Transgressive System-Tract and highstand System-Tract. 


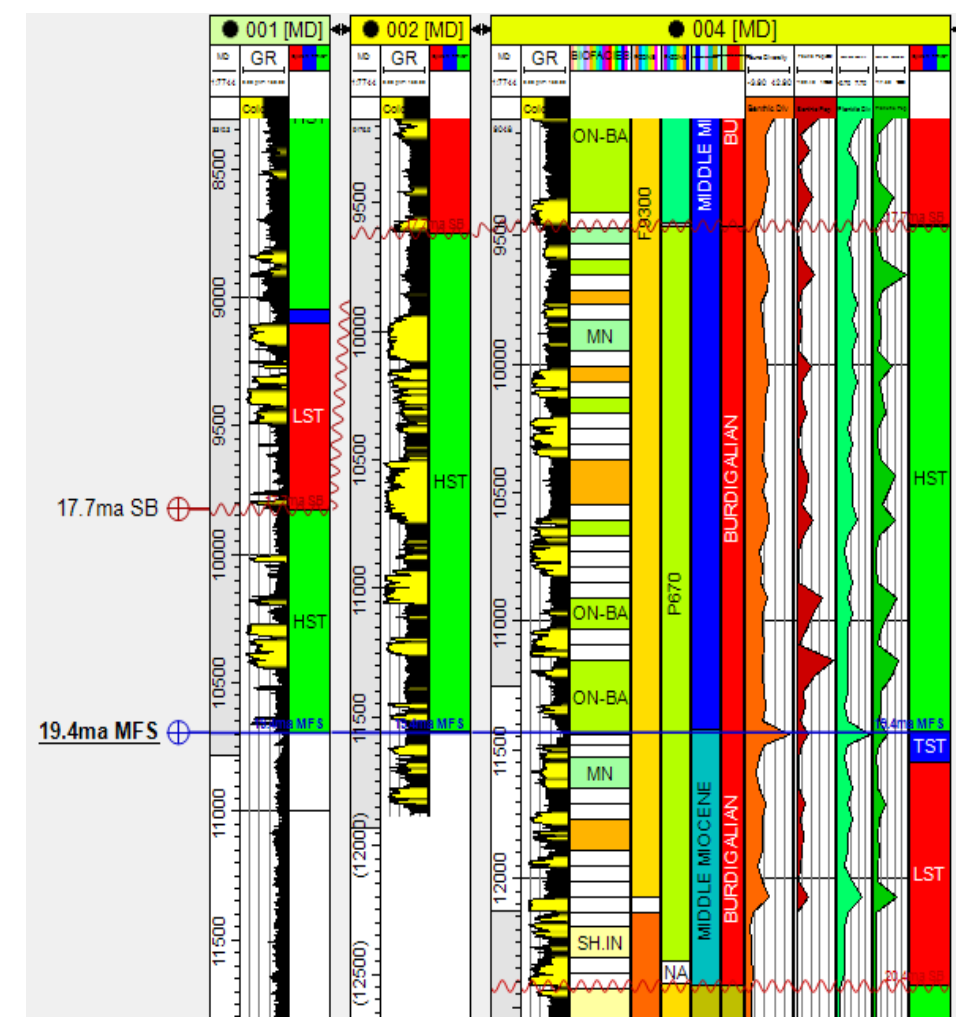

Fig 9: Well section window showing the characteristics of Sequence 2 (SQ2) in well 001, 002 and 004 flattened on MFS 19.4 Ma

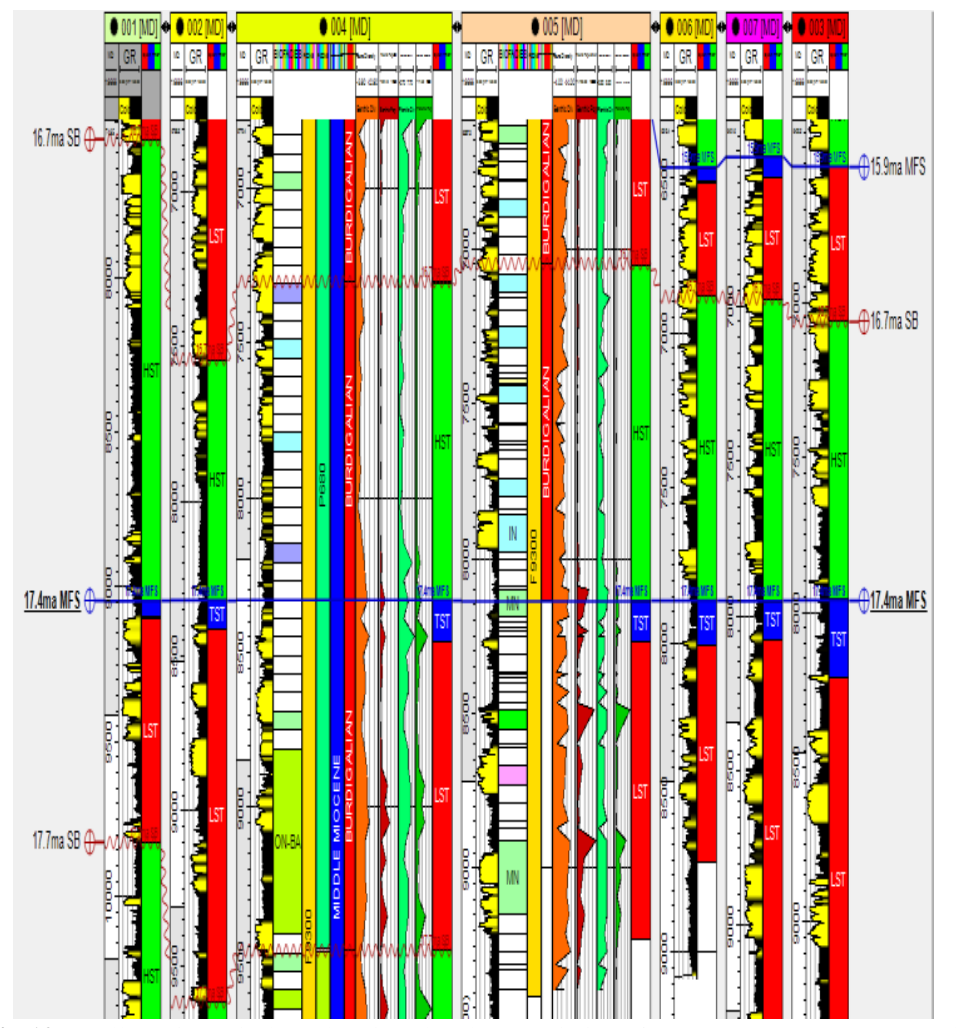

Fig 10: Well section window showing the characteristics of Sequence 3 (SQ3) across all wells in the field and flattened on MFS 17.4 Ma
The identified Transgressive System-Tract is thin and has a thickness of $97 \mathrm{ft}$ in well 004. The sequence is bounded at the base by the 20.4 Ma SB and at the top by the 17.7 Ma SB. The 19.4 Ma MFS marker (Ogara Shale) is the boundary separating the transgressive System-Tract from the Highstand System Tract. This sequence is Middle Miocene in Age. The lowstand System-Tract was laid down in the inner neritic environment. The Transgressive System-Tract was deposited in the middle neritic while the highstand System-Tract was laid down in the outer neritic to bathyal paleoenvironment environment.

Sequence 3 (SQ3): The width of this sequence varies from $1800 \mathrm{ft}$ to $2400 \mathrm{ft}$ across all the wells and is thicker in well 001 and thinner in well 006. The depositional sequence is complete in all seven wells, reflecting Lowstand, Transgressive System-Tract and Highstand System Tract. The identified Transgressive System-Tract is thin and has a thickness ranging from $<200 \mathrm{ft}$ in well 001 to about 200ft in well 003. The sequence is confined at the base by the $17.7 \mathrm{Ma} \mathrm{SB}$ and at the top by the $16.7 \mathrm{Ma}$ SB. The 17.4 Ma MFS is the boundary separating the Transgressive System-Tract from the highstand system tract (Fig. 9). This sequence is Middle Miocene in Age. The Lowstand System-Tract was laid down in the outer neritic environment. Reconstruction of environment of deposition clearly shows that the transgressive System-Tract was deposited in the middle neritic while the highstand System-Tract was laid down in the inner neritic paleoenvironment.

Sequence 4 (SQ4): The gross thickness of this sequence ranges from $850 \mathrm{ft}$ to $1300 \mathrm{ft}$ across all the wells in the field. 


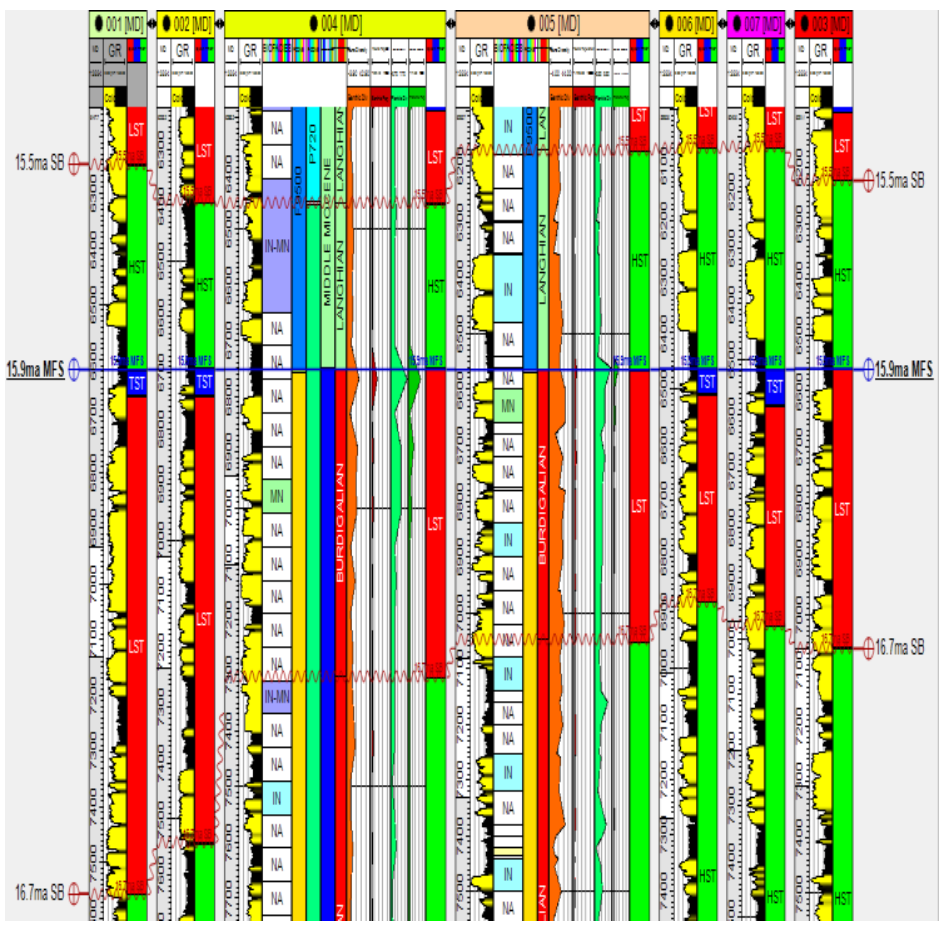

Fig 10: Well section window showing the characteristics of Sequence 4 (SQ4) across all wells in the field and flattened on MFS 15.9 Ma

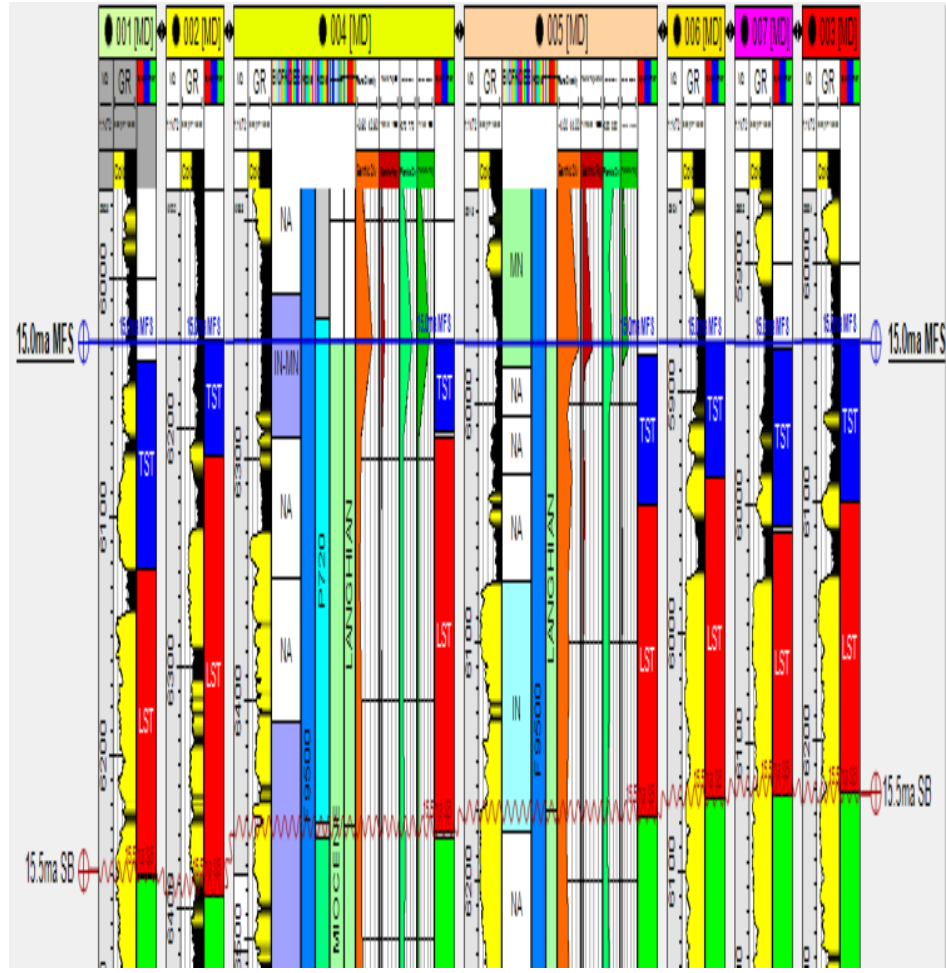

Fig 11: Well section window showing the characteristics of Sequence 5 (SQ5) across all wells in the field and flattened on MFS 15.0 Ma

The sequence is thicker in well 001 and thinner in well 003. In well 003, 004 and 005 , the depositional sequence is incomplete, reflecting only highstand and lowstand system tracts. In all other wells, the depositional sequence is complete, reflecting lowstand, transgressive and highstand system tract. The identified transgressive system-tract is thin and has a width $<80 \mathrm{ft}$ in well 003 , 004 and 005 . Generally, the sequence is confined at the base by the 16.7 Ma SB and at the top by the 15.5 Ma SB. The 15.9 Ma MFS marker (Chiloguembelina 3) is the boundary separating the transgressive system-tract from the highstand system tract. This sequence is Middle Miocene in Age. The lowstand system-tract and the transgressive system-tract were deposited in the middle neritic to middle neritic paleo-environment.

Sequence 5 (SQ5): The thickness of this sequence ranges from $180 \mathrm{ft}$ to $220 \mathrm{ft}$ across all the wells in the field. The sequence is thicker in well 002 and thinner in well 007 (Fig. 10). The identified transgressive System-Tract is thin and ranges in thickness from <30ft in well 004 to $<80 \mathrm{ft}$ in well 001 . This sequence is incomplete and has system tracts belonging to only the lowstand system-tract and the transgressive system tract. This incomplete sequence is bounded at the base by the 15.5 Ma SB and at the top by the 15.0 Ma MFS marker (Bolivina-25) (Fig.11). This sequence is Middle Miocene in Age. The lowstand System-Tract and the transgressive System-Tract were deposited in the inner neritic to middle neritic paleoenvironment.

Seismic Sequence Stratigraphic Interpretation: The continuity of the well $\log$ clearly observed sequence boundaries and maximum flooding were established on seismic data. Figure 12-15 are inline and crossline sections revealing the continuity of the marker beds. Sediment deposition and accumulation occurs in the North-South direction. The North is the inland direction while the South lies in the basin-ward direction. 


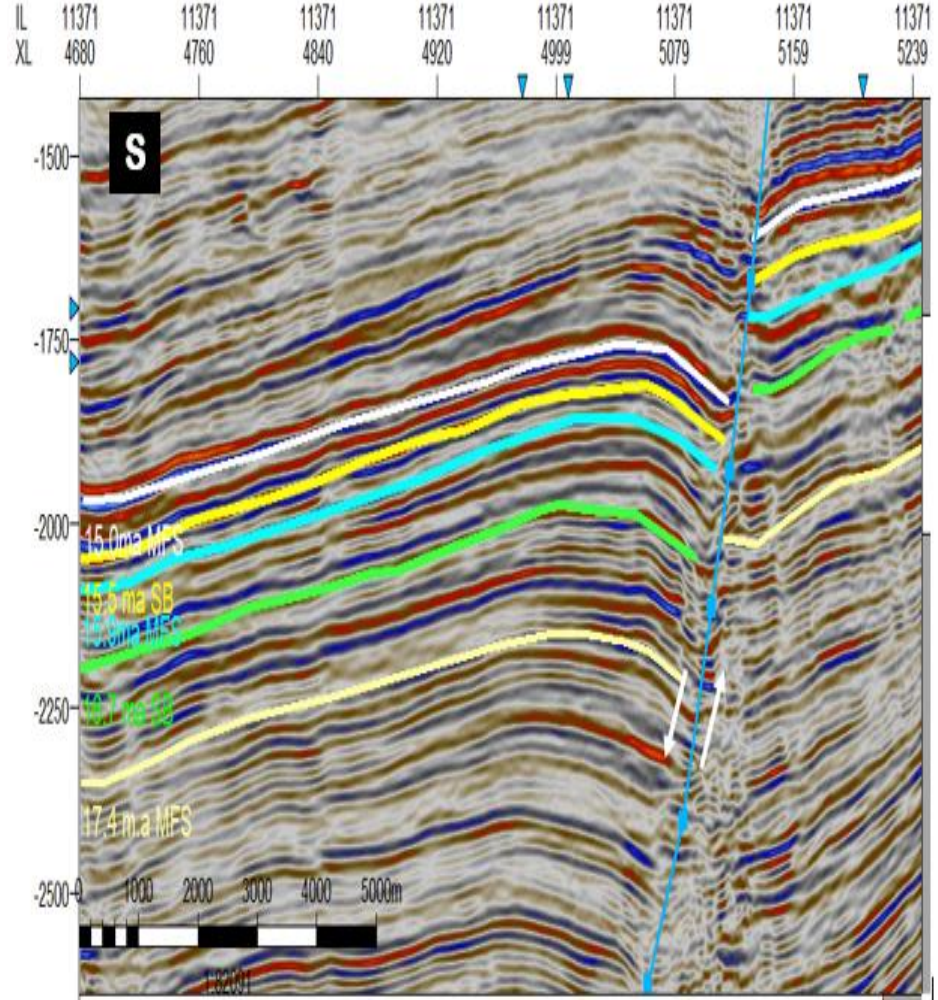

Fig 12: Seismic inline 11371 showing the continuity of the identified key stratigraphic surfaces truncated by a synthetic fault

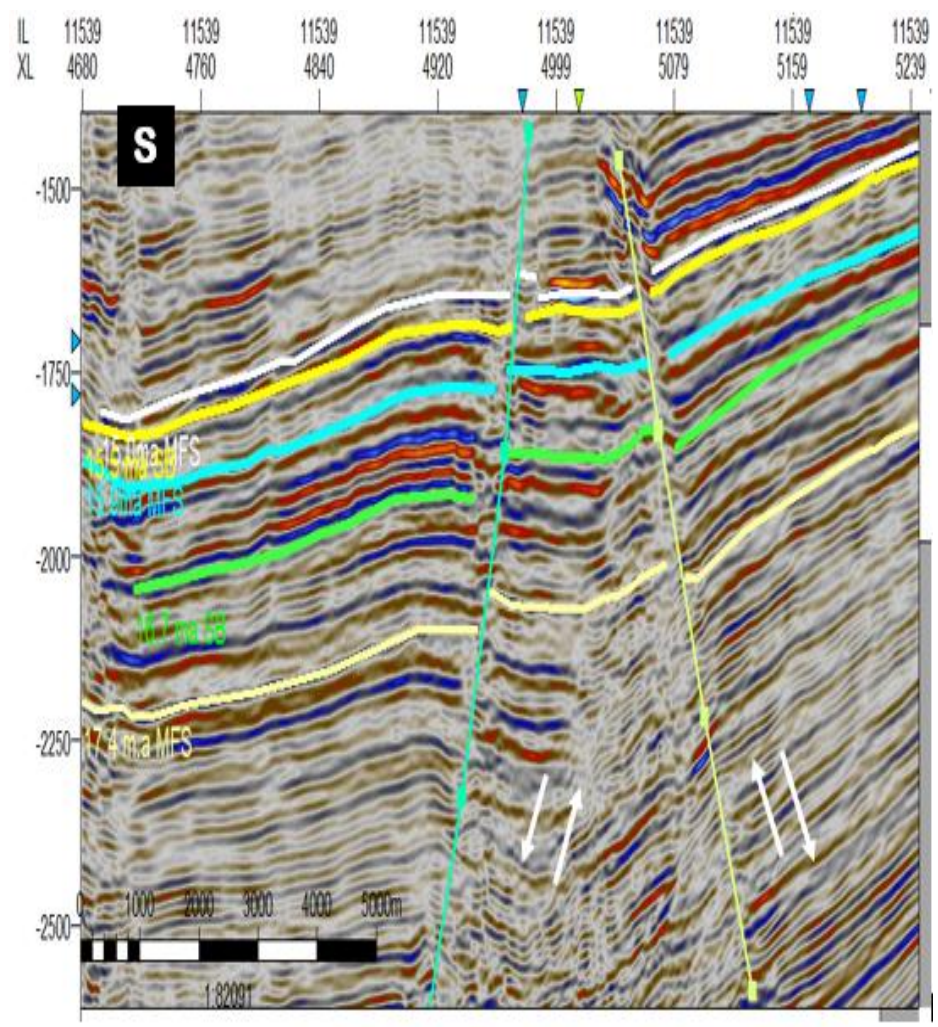

Fig 13: Seismic inline 11539 showing the continuity of key stratigraphic surfaces truncated by synthetic and antithetic faults
The seismic sections revealed that the stratigraphic sequences are thickening from North to South, indicative of shifting depositional environments. Similarly, the stratigraphic sequences thicken with an increase in depth level while the shallow stratigraphic sequences are thinner. A single channel was clearly observed on the $16.7 \mathrm{Ma}$ SB while two channels were identified on the 15.5 Ma SB. These channels were clearly observed on the crosslines and were barely noticed on the inline dimension, the channels are relatively large and the channel fill sedimentation could be seen from the behavior of the onlapping and downlapping seismic reflection termination patterns within the channel. On figure 14, the channel is noticed to erode and truncate the top part of the HST in sequence 3 (SQ3), reducing the overall width of the HST within this area. Meanwhile on figure 15, the erosional truncation which created two channels had truncated a major part of sequence 3 (SQ3) and sequence 4 (SQ4), resulting in missing sections of these stratigraphic components in some areas. The $15.5 \mathrm{Ma} \mathrm{SB}$ is a major diachronous erosional surface, truncating several other stratigraphic units. The channel created on the 16.7 Ma SB is approximately $3.0 \mathrm{~km}$ wide while the overlying channel created by the 15.5 Ma SB is approximately $4 \mathrm{~km}$ wide, with a smaller channel $<1.0 \mathrm{~km}$ wide lying at the right side of the main channel (Fig.15).

Petroleum Play Assessment: Petroleum play assessment was considered in terms of sediment thickness, sediment distribution, grain size, sediment budget, reservoir potential, source and seal potential. The HST in sequence 1 (SQ1) has a sediment thickness of $1482 \mathrm{ft}$. 


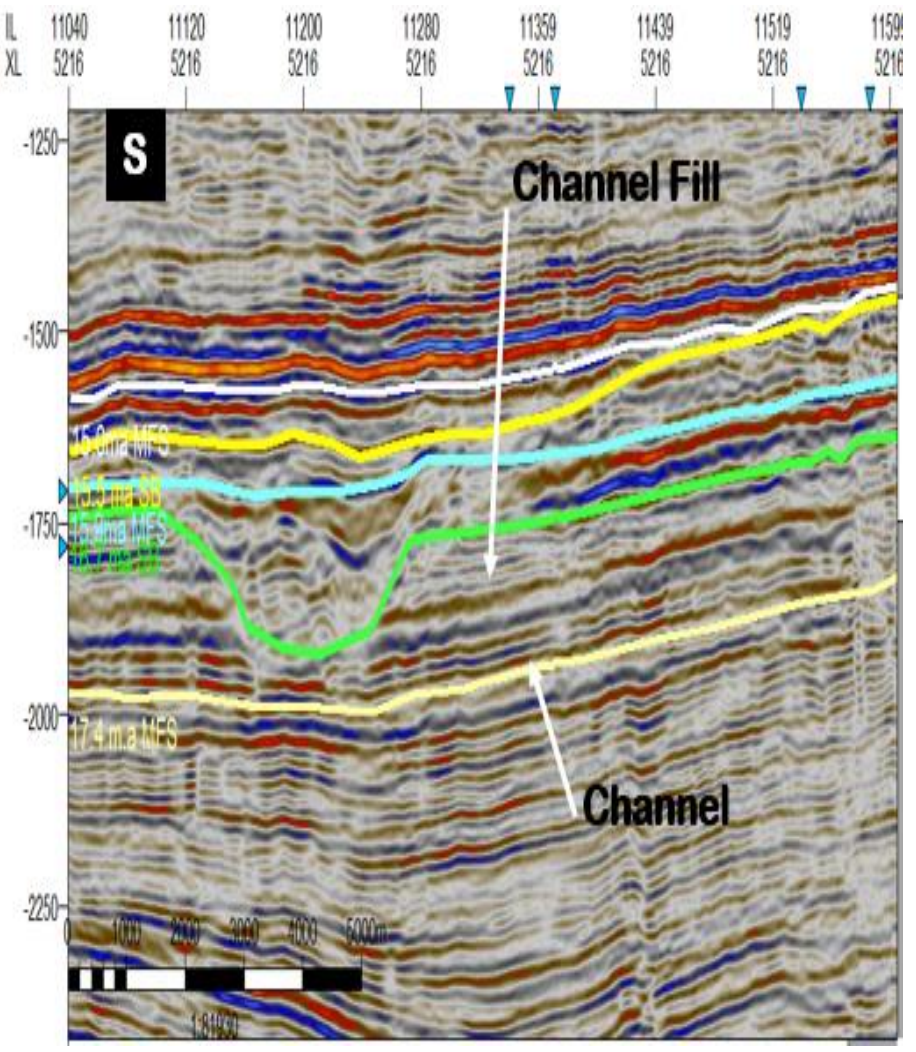

Fig 14: Crossline 5216 showing the continuity of key stratigraphic surfaces and a channel identified on the $16.7 \mathrm{Ma}$ SB

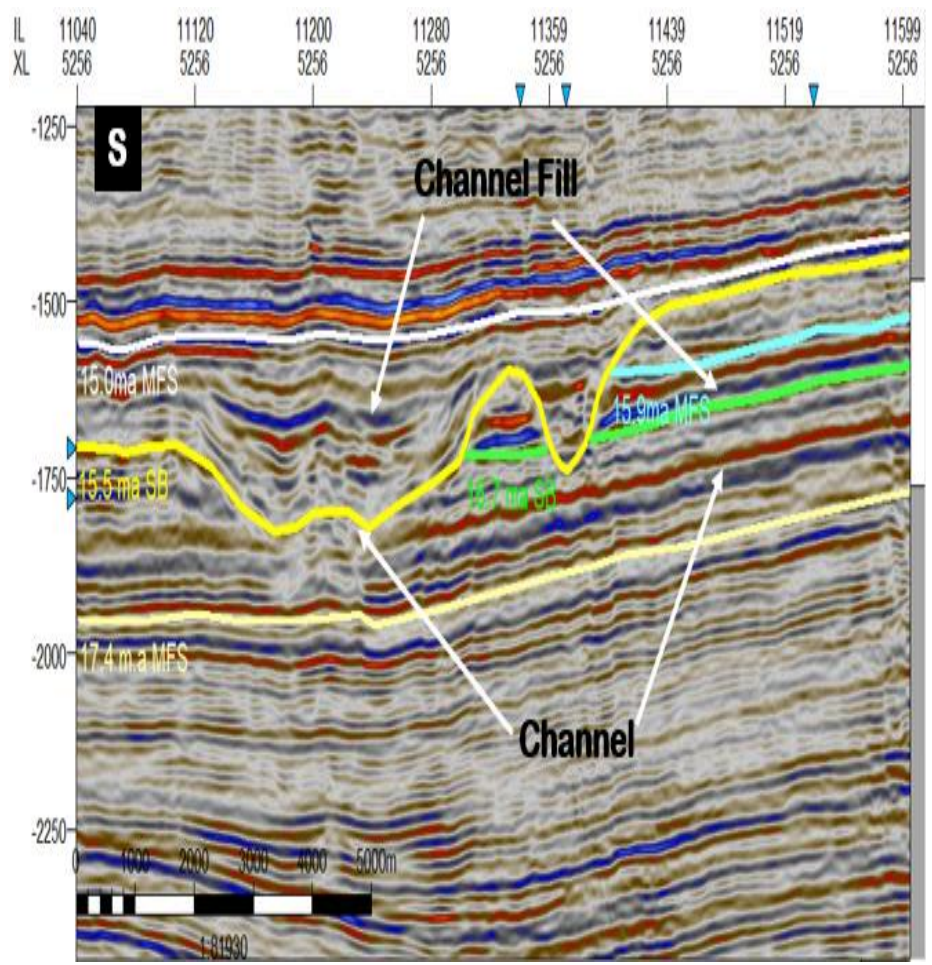

Fig 15: Seismic crossline 5256 showing the continuity of key stratigraphic surfaces and a channel identified on the $15.5 \mathrm{Ma} \mathrm{SB}$
The LST, TST and HST in sequence 2 (SEQ2) have thicknesses on average of $883 \mathrm{ft}, 97 \mathrm{ft}$ and $1405 \mathrm{ft}$ respectively. In sequence 3 (SQ3), the thicknesses of LST, TST and HST on average are $1191 \mathrm{ft}, 187 \mathrm{ft}$ and $1054 \mathrm{ft}$ respectively. The thicknesses of LST, TST and HST in sequence 4 (SQ4) on average are $642 \mathrm{ft}, 71 \mathrm{ft}$ and $607 \mathrm{ft}$ respectively. Meanwhile in sequence 5 (SQ5), only LST and TST parasequences were identified with an average thickness of $83 \mathrm{ft}$ and $150 \mathrm{ft}$ respectively. Based on the thickness, the LST and HST have sufficient sediment thicknesses. Hence, sediment budget is very good for both LST and HST but poor for the TST parasequences. In SQ1, the later part of the HST is sufficiently thicker than the earlier part. In SQ2, the early part of the LST and the HST are sufficiently thicker than the later part. Similarly, in SQ3, the early part of the LST and the HST are sufficiently thicker than the later part. Meanwhile in SQ4, the LST parasequences have a fairly even distribution from the top to the base while the HST parasequences is thicker at the early part and thinner at the later part. For the SQ5, the LST is thicker at the early part and thinner at the later part. The TST parasequences are relatively thin, with the top tending towards shales in all five sequences. The sandstone facies and the shaly sandstone facies predominates in the LST and HST parasequences, with minor heterolithic facies occurring predominantly at transition zones from one system tract to another. In general, sandstone facies are more predominant at the upper sequences while shaly sandstones facies are more prevalent at the lower sequences. Since sandstone facies are more predominant at the upper sequences, the sands are thickening towards the top, indicating that the grain size increases from SQ1 to SQ5.. 
Although grain size increases from SQ1 to SQ5, the overall thickness of the sequences decreases from SQ1 to SQ5. Sequence 5 (SQ5) has the smallest thickness compared to all the other sequences. Seismic sections revealed that the sequences are thicker at the base and thinner towards the top (SQ1>SQ2>SQ3>SQ4>SQ5). Reservoir potential considers the thickness of the sands in each system tract, the cleanliness of the sand bodies, the grain size and sorting of the grains. The HST sands have the highest thickness, and this is closely followed by the LST reservoir sands. The TST sands have very small sand thicknesses. In terms of cleanliness, the LST sands appear cleaner than the HST. Although both HST and LST have significant shaliness, the concentration is higher in the HST parasequences at all the identified sequences. Large channels identified in the LST of both SQ4 and SQ5 are very good reservoirs. Generally, the reservoir sands cleanliness increases with decreasing depth and so does the grain size. The LST and HST both have progradational and aggradational parasequence stacking patterns and hence both have coarsening upward and a blocky even grain sized motif. Side wall samples revealed that the sands are predominantly medium to coarse grained with minor fines and moderately sorted to well sorted. These are requirements for good quality reservoir sand. The sands of the HST and LST are also loosely unconsolidated. The TST and overlying MFS are good source and seal rocks in the field. Overlying the channels identified in SQ4 and SQ5 are shales of the TST which is capped by the MFS. The channels of the LST in SQ4 are juxtaposed against shales from both the TST and the MFS, this shows that the channels have a good sealing mechanism in the horizontal dimension. Generally, the field has very good source and seal potential as found from the numerous shale interbeds found within each system tract across all five sequences. Both source and sealing potential are better with increasing depth. Hence, based on source and seal potential, SQ1>SQ2>SQ3>SQ4>SQ5

This research focused on facies and sequence stratigraphy study of BEMA field which utilized well logs, side wall samples, biostratigraphic data and 3-D seismic. It was aimed at identifying the various facies, building a sequence stratigraphic framework for accurate knowledge of the dispersal of the observable facies within the field and then determines the petroleum play assessment of the identified system tracts. Four facies were identified across the field; these were sandstone facies, shaly-sandstone facies, heterolithic facies and mudrock facies. The sandstone facies are fine to coarse grained, brownish, moderately to well sorted and loosely consolidated. The sandstone Facies have blocky to bell shaped motifs, indicative of channel and higher shoreface depositional environment. The shaly sandstone facies are fine to medium grained, silty, moderately sorted and loosely consolidated. Heterolithic Facies are found as thin sand-shale beds juxtaposition. The facies are basically related with blocky and funnel shaped motifs with several serrations. Heterolithics facies are usually revealing of lower shoreface environmental setting. The mudrock facies are dark to grey and very calcareous. The facies contain high abundance and diversity of marine fossils indicative of marine environmental settings. The sequence stratigraphic study revealed various characteristics of several events of transgressive and regressive events which are correlated with the universal chronostratigraphic planes such as the MFS and/or sequence boundaries. From detailed well-log sequence stratigraphic study, revealed the Bema field of comprising nine stratigraphic bounding surfaces (Five Maximum Flooding Surfaces (MFSs) with ages ranging from 20.7 to $15.0 \mathrm{Ma}$, and Four Sequence Boundaries (SBs) with ages between 20.4 and 15.5 Ma respectively). The stratigraphic correlation of the surfaces, reveals the genetic units of LST, TST and HST throughout the entire section. Further study revealed the genetic components of LST (sands with minor shale interbeds), TST (shale) and HST (sands and shales) which make up the reservoir and source/seal rock packages in the study wells. Five Vail's third order depositional sequences (SQ1, SQ2, SQ3, SQ4, and SQ5) and four (4) Galloway's genetic sequences (GQ1, GQ2, GQ3 and GQ4) were recognized within the study area based on stratigraphic marker tops and system tracts. The structures identified on the seismic section were mostly listric regional faults which clearly extend down the basin. Majority of these faults are synthetic and dips in the direction of regional stratigraphy (N-S) as well as a few antithetic faults were identified and dips in the reverse direction to regional stratigraphy. Hydrocarbon play assessment revealed that the HST and TST are key reservoir rocks in the field while the shale of the TST therefore forms the seal for the potential traps in the study area. Several large channels were recognized on the seismic as reservoirs that were associated with LST with TST shales overlying the channels deposits and creating very good caprock/sealing mechanism. The alternation of the LST, HST and TST sands and shale with associate synthetic and antithetic faults gave rise to a combination of reservoir and seal rocks that are vital for hydrocarbon buildup and entrapment. Generally, grain size, cleanliness of the reservoir and sorting increases with decreasing depth while the width of the reservoirs decreases with decrease in depth. Based on this assessment, the shallower sequences have better quality than the deeper 
depositional sequences but lack enough width. The best proceeds in the field are generally related with zones of the synthetic and antithetic faults and also channels within the lowstand System-Tract identified in sequence 4 and sequence 5 .

Conclusion: Generally, this research has given more understanding of facies architecture and sequence stratigraphic framework of the Central Swamp depobelt, onshore Niger-Delta. Well stratigraphic correlation and event mapping on seismic has greatly assisted in showing continuity and good hydrocarbon prospective areas such as large channels. Five third order depositional sequences (SQ1, SQ2, SQ3, SQ4, and SQ5) were recognized based on stratigraphic marker surfaces and system tracts. The HST's and LST's were interpreted as the reservoir rocks while the TST's as the source and seal rocks in the field. The HST and LST of the shallower sequences are of better quality than the lower stratigraphic sequences.

\section{REFERENCES}

Allen, J.R.L (1965). Late Quaternary Niger Delta and Adjacent Areas: Sedimentaery Environments and lithofacies. Bulletin of the American Association of Petroleum Geologist, 49, 547600.

Adegoke, O.S; Oyebamiji, A.S; Edet, J.J; Osterloff, P.L; Ulu, O.K (2017). Cenezoic Foraminifera and Calcareous nannofossil biostratigraphy of the Niger Delta, Cathleen Sether, United States, 570 .

Boggs, S. (Jr.) (2014). Principles of Sedimentology and Stratigraphy Fourth Edition, 101.

Bilotti, F (2005). Structural Styles in the Deep-Water fold and Thrust Belts of the Niger Delta: AAPG Bulletin, 89, 753-778.

Corredor, F; Shaw, J. H; Bilotti, F. (2005): Structural styles in the Deep-Water Fold and Thrust belts of the Niger delta: AAPG Bulletin, 89, 753-778.

Damuth, J. E. (1994). Neogene gravity tectonics and Depositional Processes on the Deep Niger Delta continental margin: Marine and Petroleum Geology, vol.11, (3), 320-343.

Doust, H; Omatsola, E. (1990). Niger delta: in J. D. Edwards and P.A. Santogrossi, eds. Divergent/Passive Margin Basins: AAPG Memoir 48, 239-247.
Ejedawe, J.E; Coker, S. J. L; Lambert-Aikhionbare, D.O. (1984). Evolution of oil-Generative Window and oil and gas occurrence in Tertiary Niger Delta basin: AAPG Bulletin, 68, 17441749.

Embry, A.F. (2009). Practical Sequence Stratigraphy. Canadian Society of Petroleum Geologists, 0-65.

Emery, D; Myers, K., (1996): Sequence Stratigraphy. Blackwell ScienceLtd: London, Uk, 200-250

Evamy, B.D; Haremboure, J., R; Kammerling, Knaap W.A; Molloy, F.A; Rowlands, P. H; (1978). Hydrocarbon habitat of tertiary Niger Delta: American Association of Petroleum Geologists Bulletin, 62:1-39.

Feely, M.H; Moore, T.C. (Jr); Loutit T.S; Bryant W.R; (2005). Sequence Stratigraphy Of Mississippi Fan Related To Oxygen Isotope Sea Level Index. American Association of Petroleum Geologists Bulletin, 7, 407.

Galloway, G.E. (1989). Genetic Stratigraphic sequences in basin analysis1: architecture and genesis of flooding-surface bounded depositional units. American Association of Petroleum Geologist Bulletin, 73, 125-142.

Haack, R.C.; Sundararaman, P; Dahl, J; (1997). Niger Delta petroleum System. Extended Abstracts, AAPG/ABGP Hedberg Research Symposium, Petroleum Systems of the South Atlantic Margin, Rio De Janeiro, Brazil, November 1619, 1997,.

Knox, G.J; E.M. Omatsola; (1989). "Development of the Cenozoic Niger Delta in Terms of the "Escalator regression" Model and Impact on Hydrocarbon Distribution". Proceedings KNGMG Symposium, Coastal Lowlands, Geology, and Geotechnology. Dordrecht, Kluwer. 181-200

Liangqing, Xue; Galloway, W.E; (1993). Genetic Sequence Stratigraphy Framework, Depositional Style and Hydrocarbon Occurrence of the Upper Cretaceous Qin Formation in: the Songlian Lacustrine Basin, North-Eastern China. American Association of Petroleum Geologists Bulletin, 7, 407.

Nichols, G; (2009). Sedimentology and Stratigraphy, 2nd ed. Wiley-Blackwell publishers, 432. 
Posamentier, H.W; Allen, G.P; (1999). Concepts and applications of Siliciclastic Sequence Stratigraphy. 210pp

Posamentier, H.W; Vail, P.R; (1988). Eustatic controls on clastic deposition II: Sequence and System Tract model. In: Wilgus, C.K., Hasting, B.S., Kendall, C.G.S.C., Ross, C.A., Van Wagoner, J.C. (eds). Sea level changes: an integrated approach. Society of Economic Paleontologists and Mineralogist special publication, 42. 125154

Reijers, T.J.A; (1995). Reservoir geological Core fiscription using standardized lithofacies and their associations in the Tertiary Niger Delta. NAPE Bulletin, 10, 27-39
Short, K. C; A. J. Stauble; (1967). Outline of Geology of Niger Delta: American Association of Petroleum Geologists Bulletin 51, 761-779.

Stacher, P; (1995). Present understanding of the Niger delta hydrocarbon habitat, in Oti, M. N. and Postma, G., eds., Geology of Deltas: Rotterdam, A.A. Balkema, 257-266.

Steele, D; Ejedawe, J; Adeogba, T; Grant, C; Filbrandt, J; Ganze, H; (2009). Geological Framework of Nigeria Linked Shelf Extension and Deepwater Thrust Belts.

Wheeler, H.E; Murray, H; (1957). Base level control patterns in Cyclothemic Sedimentation: American Association of Petroleum Geologists Bulletin, 41, 1985-2011. 